\title{
A Comparative Analysis of Ginger Cultivation Methods in Kurmin-Jatau, District of Jaba Local Government Area, Kaduna State, Nigeria
}

\author{
Samaila Alhassan Sati ${ }^{1 *}$ and Gideon Bala ${ }^{1}$ \\ ${ }^{1}$ Department of Geography, Nigerian Defense Academy, Kaduna, Nigeria.
}

Authors' contributions

This work was a combined effort of both authors. Author SAS designed the study and wrote the methods, discussion and conclusion, while author GB carried out the literature search, field work and wrote the results section of the manuscript. Both authors read and approved the final manuscript.

Article Information

DOI: $10.9734 /$ AJSSPN/2017/34183

Editor(s):

(1) Prof. Rusu Teodor, Department of Technical and Soil Sciences, University of Agricultural Sciences and Veterinary Medicine Cluj-Napoca, Cluj-Napoca, Romania.

Reviewers:

(1) Eliton da Silva Vasconcelos, Federal University of São Carlos - UFSCar, Brazil. (2) Bilal ahmad Lone, Shere E Kashmir university of Agricultural sciences and technology Kashmir, India. Complete Peer review History: http://www.sciencedomain.org/review-history/19713

Original Research Article

Received $17^{\text {th }}$ May 2017

Accepted $24^{\text {th }}$ May 2017

Published $27^{\text {th }}$ June 2017

\section{ABSTRACT}

Aim: The aim of this study was to evaluate the Flatbed, Mound or Raised and Ridges tillage practices to identify the best with relatively higher yield of ginger but with minimum soil erosion problems.

Place and Duration of Study: The study was carried out in Kurmin-Jatau, Jaba Local Government Area, Kaduna State, Nigeria for a period of ten months.

Study Design: The experimental design took three forms; slope measurement to attain the desired slope on the farms, obtaining data on eroded materials, and generating data on plant growth/features.

Methodology: The three tillage methods (Flatbed, Mound, and Raised) were prepared to determine yield and erosion problems. Data on the study were obtained from direct measurement on the experimental farms, interview and questionnaire methods, as well as related literature.

Results: The Flatbed tillage method encouraged growth of almost all the plant attributes, most especially the number of tillers which is the major determinant of ginger yield, followed by Ridges and the least was in Mounds tillage method. Statistical analysis of the data generated on this showed a significant relationship between the variables $\left(F_{c}=8.84>F_{t}=3.89 ; \alpha=0.05 ; f d=12\right.$ and 2$)$. 
There was also appreciable difference in run-off and eroded soil particles, with the highest value recorded in the Mounds tillage practice followed by the Ridges and then the Flatbed tillage practice. Using analysis of variance, a significant relationship was established between the three tillage methods and the quantity of soil materials carried by run-off $\left(F_{c}=7.58>F_{t}=3.55 ; \propto=0.05\right.$; $d f_{1}=2$ and $\left.d f_{2}=18\right)$. Increased rhizome yield of ginger crop and amount of soil eroded particles was recorded on Flatbed tillage system as compared with Mounds and Ridges.

Conclusion: Flatbed method of cultivating ginger crop has been shown to still be promising, but farmers should increase their knowledge on soil erosion management and use of other farming inputs and technologies.

Keywords: Ginger; tillage methods; flatbed; mounds; ridges.

\section{INTRODUCTION}

Tillage is one of the major factors for increasing yield of crops since it induces nutrient release, decomposition of organic materials and mineralization of organic nutrients [1]. Excessive tillage has been associated with degradation of the biological, chemical, and physical qualities of the soil [2]. Obtained from the archives of Kaduna state agricultural Development Project [3]; ginger cultivation in the state has been on for approximately nine (9) decades, and the common tillage method used by farmers in this area is the Flat bed method. According to [4], cultivation on the same piece of land may affect yield and soil fertility. Since the common method of ginger cultivation employed by farmers in the study area (Kurmin-Jatau) is the Flatbed, there is need to experiment other tillage methods to see how it will affect yield and soil erosion problem. Therefore, the study was conducted to compare the effect of different tillage methods (Flatbed, mounds and ridges) on ginger yield in the study area.

\subsection{Problem of the Study}

Ginger cultivation in Kurmin-Jatau in the Southern part of Kaduna State has been on Flatbeds by farmers in this area since its inception, inherited from fore fathers. This may be as a result of ignorance about other methods. There appears to be relative decline in ginger yield while soil erosion seems to be on the increase in this area. This has led ginger farmers to put enormous pressure on the available land, to the extent of farming on marginal land, which may be unsustainable. There are other methods of ginger cultivation which are being practiced in other parts of the world; such as Mounds or Raised bed system in India, and the Ridges system in China [5]. Method of tillage or the planting system has great effect on the yield of any crop which ginger is not an exception. This is because it determines the growth of the crop from the root to the flowering stage. Yet research methods on tillage requirements of ginger and the implications for productions of the crop in the study area do not seem to have drawn the attention of researchers. This work, therefore, attempts to address that gap.

\section{MATERIALS AND METHODS}

\subsection{Study Area}

Kurmin-Jatau is a district in Jaba Local Government area of Kaduna State. It constitutes four villages namely Ungwan Galadima, Ungwan Gauji, Ungwan Sanyi and Kurmin Jatau as the headquarters. It lies between latitudes 935' N and $937^{\prime} \mathrm{N}$, and Longitudes $756^{\prime} \mathrm{E}$ and $80^{\circ} \mathrm{E}$, as well as altitude 2509 feet. It is located in the northern Guinea Savannah zone of Nigeria, and it is bordered by Kanyi to the south, Gantan to the North, Kurmin Dangana to the West and to the Fai to the East. The climatic condition of the study area is the type of tropical continental climate with distinct seasonal regimes, oscillating between cool to hot dry and humid to wet. These two seasons reflect the influences of tropical continental and equatorial maritime air masses which sweep over the entire country. The rainy season normally sets in around April and lasts for 5 months, while the dry season starts from around November and lasts for about 7 months. The mean annual rainfall can be as high as 2000 $\mathrm{mm}$ [6]. The study area is located in the Guinea Savannah climatic belt, the most extensive vegetation belt in Nigeria, covering nearly half of the country. It exhibits characteristics such as woodland, shrubs and long grasses with gallery of forest along the main water courses. However, these vegetation 


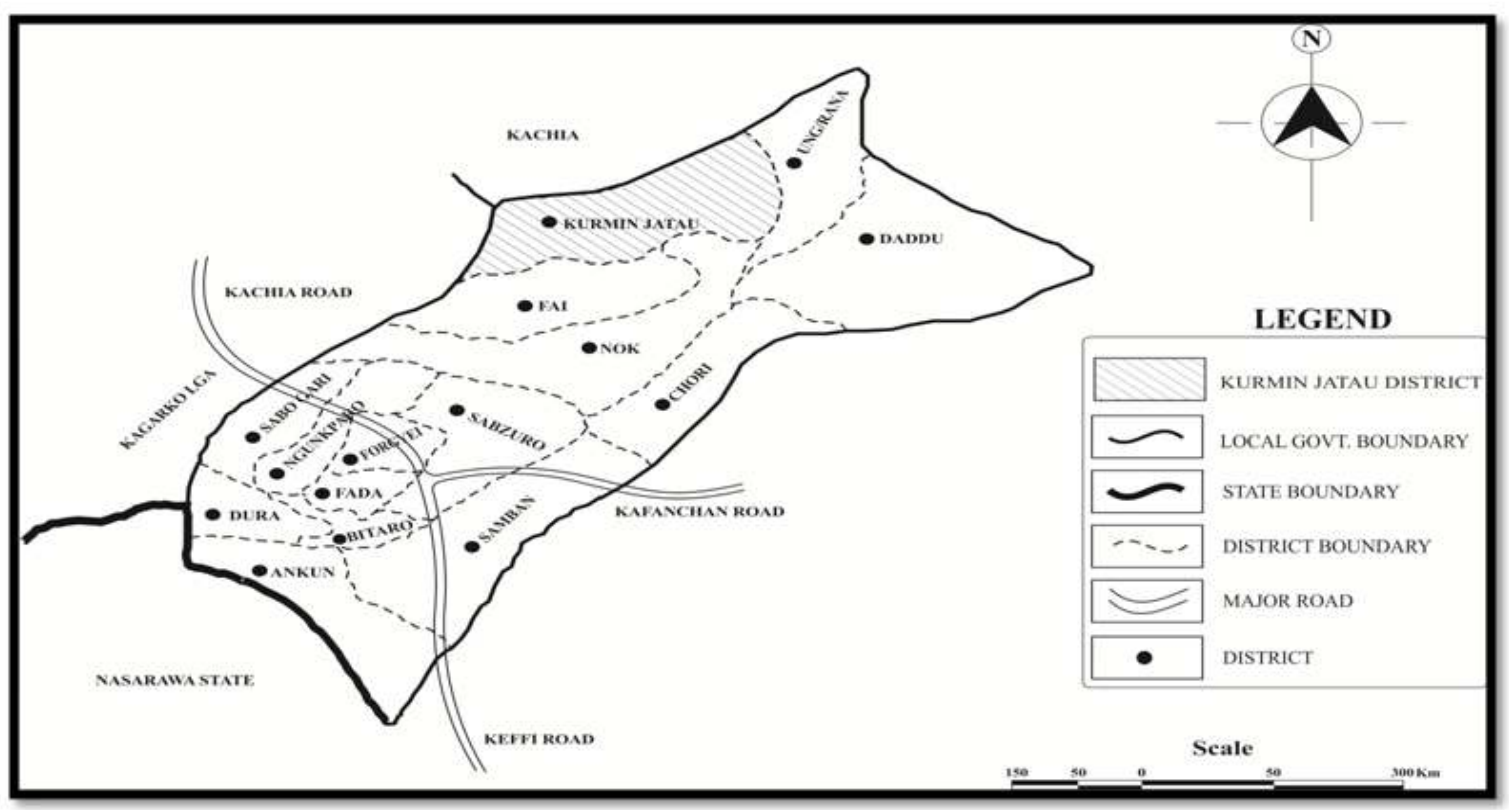

Fig. 1. Jaba local government showing Kurmin-Jatau District

features are no longer the same in the study area due to poor management practices, like cutting down of trees for fuel wood, continuous cultivation, overgrazing and bush burning (field observation). The predominant tree species in the study area are sheer butter trees (Vitellaria paradoxa), locust beans (Parkia biglobosa) and mango (Magnefera indica). Other less frequent shrubs species include Butyrospernum, Vitex, Termmalia and Pilostigma (field Observation).

\subsection{Data Collection}

Two types of data were collected for the study namely primary data and secondary data. Primary data obtained from selected farmers were on size of ginger farm normally cultivated in meter square per year, level of production in bags per year, size of family, methods of ginger cultivation, additional labour, length of period/ time spent as a ginger farmer or in farming ginger, performance of ginger and erosion. Direct measurement on the experimental farms, interview and questionnaire methods were employed. Secondary data were obtained from related literature.

\subsubsection{Data on ginger farmers}

Oral interviews were conducted with farmers from selected households using a structured questionnaire. Using a systematic sampling method, 5 households were selected at regular intervals on each street chosen so as to enable a representative fraction of the entire study area. A total of 300 copies of the questionnaire were used due to the relatively small size of the population of the study area.

\subsubsection{Experimental design for generating data on the farm}

The experimental design took three forms; slope measurement to attain the desired slope on the farms, obtaining data on eroded materials, and generating data on plant growth/features.

\subsubsection{Slope measurement}

Using Forest Management Practices Fact Sheet Managing Water (2002) the experimental field was leveled to achieve the gradient so as to control the flow of the run-off. The Equipment required for this experiment included; shovels and hoes, two range poles, string or rope, permanent marker or tape, plump, and a ruler.

Procedure: The experimental farms were cleared manually. Grass cut was gathered and with pegs the three experimental farms were marked out to a size of $15 \mathrm{~m} \times 30 \mathrm{~m}$ each. For each range pole, starting from the bottom or the sharp edge, marks were made for every $2 \mathrm{~cm}$ with a marker. One end of the string, about $35 \mathrm{~m}$ 
long, was firmly tied to the sharp edge of the pole at the $2 \mathrm{~cm}$ mark, then the pole was fixed to the beginning of the experimental farm and the second pole was also fixed to the ground at a depth the same with the first pole at the end of the farm. Then the string was pulled with a plump attached to it to the second pole, holding the loose end of the string sliding it up or down until the plump indicated that the string was leveled. The distance the string had to be moved up or down at the second pole is the difference in elevation between the two points. Then the change in elevation was divided by the distance between the two poles. The percent slope was calculated by multiplying the figures obtained in the above division by 100 .

$$
\begin{aligned}
& \{\% \text { slope }=(\text { change in elevation/horizontal } \\
& \text { distance }) \times 100\}
\end{aligned}
$$

\subsubsection{Data on eroded soil}

A direct measurement test was carried out on the three tilled farms to determine the rate of erosion in each by run-off. Materials required include: empty plastic bucket or a jug, pegs, measurement tape, shovel, oven and baking sheets or pie tins for drying soil samples, scale for weighing dried soil samples.

Procedure: The experimental design that was adopted for the study was a Randomized Complete Block Design (RCBD) consisting of three treatments replicated five times. This design was chosen to compare the effects of the treatments and also to be able to compare the reliability of the experiment by coefficient of variation. With pegs and measuring tape, the three experimental sites were curved out to a size of $15 \mathrm{~m} \times 30 \mathrm{~m}$ each, which gives an area of $450 \mathrm{~m}^{2}$ for each of the experimental sites. Each site was bounded with earthen materials to a height of about $0.3 \mathrm{~m}$ to $0.4 \mathrm{~m}$ above the ground surface; to avoid surface runoff from the surrounding fields running into the experimental farm as well as preventing run-off within the experimental farm from escaping into the encompassing fields. At the lower end of each experimental farm, a slot of $1.0 \mathrm{~m} \times 1.0 \mathrm{~m}$ wide with a depth of $0.5 \mathrm{~m}$ to $0.6 \mathrm{~m}$ was created for each experimental farm as an outlet to allow runoff and eroded soil to be collected in a plastic bucket. A cover of corrugated iron sheet was placed over each pit to prevent direct rainfall from entering the plastic bucket collector. The runoff was collected after each rain storm and this was done when the rainy season was at its peak (between July and August) in the study area. Ten heavy storms were selected using the rain gauge as a guide. The runoff samples collected were separated from the eroded soil after a maximum settlement had taken place. The run-off was measured before being separated from the eroded material and the eroded soil was dried, weighed, and stored. The average of samples (run-off and eroded material) collected was calculated and coefficient of variation was obtained using the Statistical Package for Social science (SPSS) to compare the results from the three experimental sites.

\subsubsection{Ginger cultivation}

The ginger was divided into seed pieces either by breaking the rhizome with hand or using sharp knives for more even sizes. The rhizomes were cut into pieces of $1 \mathrm{~cm}$ to $4 \mathrm{~cm}$ each containing at least one bud. The prepared seeds were stored in a ventilated, cool and shady position in clean, sterilized bags few weeks before planting to allow the buds to start developing and the cut surfaces to dry to reduce chances of rotting. On a scale of less than 1 in 5 using the method of slop measurement described above, the three experimental farms were tilled to the desired format for the research (flatbed, mounds, and ridges). Organic additives such as poultry, goats and cow manure were incorporated for best production living the farm well drained and free of rocks. Planting materials were carefully selected so that they will be nematodes and fusarium free. Planting was done at $20 \mathrm{~cm} \times 20 \mathrm{~cm}$ spacing, $5 \mathrm{~cm}$ depth and covered with top soil to allow proper germination and subsequent growth. This was done a few days after the preparation of flatbeds, mounds or raised beds and ridges.

All mulching materials (dry grass or fresh leaves) were applied to control the level of solar radiation and retain moisture on the newly planted seed and this was done either immediately after planting or two days after planting. Additional fertilizer was applied at about 4 to 5 months after planting to boost growth and yield of the crop. Weeding was also done at about 5 to 6 months after planting to reduce competition for nutrients between the crop and grasses.

\subsubsection{Measurement of the crop attributes}

The experimental sites were divided into quadrants of $1.0 \mathrm{~m}^{2}$ and a systematic sampling 
method was employed whereby a quadrant was selected after 5 quadrants in each of the different experimental farms. Each ginger plant in the selected quadrants was measured in terms of its height, leaf length and leaf width using vernier clipper and meter rule. The number of leaves and tiller per stand were also counted. These data generation was done in a number of selected days, starting from 150, through 157, 164, 171, 178 to 185 days after planting. These days were selected because they represented the days that recorded significant differences in the growth attributes of the crop.

\subsubsection{Harvesting method}

The matured rhizome was harvested after 7-10 months with a hand hoe or barehanded for those planted in pots. The residual sand and dried leaves were carefully removed. The yield collected was weighed while fresh and dry.

\subsection{Data Analysis}

Data obtained from the three farms and the farmers were analyzed using analysis of variance (ANOVA) to test the strength of the relationships of means of the variables investigated. The results were then presented in the form of tables and graphs.

\section{RESULTS}

\subsection{Data on Ginger Farmers}

Results obtained on ginger farmers are shown in Tables 1-7. Most of the ginger farmers are between the middle and old age categories; they have spent years in its cultivation being the major trade of the people in that area. Majority of the farmers were low income earners, with very few medium and high income earners. They had at least one form of educational qualification or the other, where those with relatively higher educational attainment easily predisposed to adopting new modern techniques than the others. Different farm sizes were reported depending on the family's income. Ginger harvest in this area was reported as poor with few exceptions. Majority of the farmers depended mostly on organic manure (cow dung) followed by chemical fertilizers, and least were those that spent long time on their farms to make for other inputs such as fertilizers not available to them (Fig. 2). Flatbed method was reported as the most commonly used, while mounds method was not adopted by the farmers.

Table 1. Distribution of respondents according to age

\begin{tabular}{llllllll}
\hline Years & $\mathbf{2 0 - 3 0}$ & $\mathbf{3 0 - 4 0}$ & $\mathbf{4 0 - 5 0}$ & $\mathbf{5 0 - 6 0}$ & $\mathbf{6 0 - 7 0}$ & $\mathbf{7 0 - 8 0}$ & Total \\
\hline No. of Farmers & 11 & 23 & 29 & 36 & 68 & 60 & $\mathbf{3 0 0}$ \\
Percentage & 1.3 & 2.3 & 3.0 & 4.3 & 9.0 & 20.3 & $\mathbf{1 0 0}$ \\
\hline
\end{tabular}

Table 2. Length of time spent as ginger farmers

\begin{tabular}{llllllllll}
\hline Years & $\mathbf{1 - 5}$ & $\mathbf{5 - 1 0}$ & $\mathbf{1 0 - 1 5}$ & $\mathbf{1 5 - 2 0}$ & $\mathbf{2 0 - 2 5}$ & $\mathbf{2 5 - 3 0}$ & $\mathbf{3 0 - 3 5}$ & $\mathbf{3 5 - 4 0}$ & Total \\
\hline No. of Farmers & 9 & 13 & 14 & 16 & 32 & 61 & 76 & 79 & $\mathbf{3 0 0}$ \\
Percentage & 1.3 & 2.3 & 3.0 & 4.3 & 9.0 & 20.3 & 25.3 & 26.3 & $\mathbf{1 0 0}$ \\
\hline
\end{tabular}

Table 3. Household annual income for respondents

\begin{tabular}{lllll}
\hline & \multicolumn{3}{c}{ Categories of annual income (thousand naira) } & Total \\
\cline { 2 - 4 } & Low(<21.6) & Medium(21.7-72.0) & High $>\mathbf{7 2 . 0}$ & \\
\hline No. of farmers & 180 & 110 & 10 & $\mathbf{3 0 0}$ \\
Percentage & 60 & 36.7 & 3.3 & $\mathbf{1 0 0 \%}$ \\
\hline
\end{tabular}

Table 4. Educational qualification of farmers and willingness to adopt new methods

\begin{tabular}{lllllll}
\hline & $\begin{array}{l}\text { Never been } \\
\text { to school }\end{array}$ & $\begin{array}{l}\text { Adult } \\
\text { education }\end{array}$ & $\begin{array}{l}\text { Primary } \\
\text { school }\end{array}$ & $\begin{array}{l}\text { Secondary } \\
\text { school }\end{array}$ & $\begin{array}{l}\text { Tertiary } \\
\text { education }\end{array}$ & Total \\
\hline No. of farmers & 7 & 14 & 160 & 90 & 29 & 300 \\
Not ready to adopt & 7 & 10 & 125 & 43 & 0 & 185 \\
Ready to adopt & 0 & 4 & 35 & 47 & 29 & 115 \\
\hline
\end{tabular}


Table 5. Sizes of farms cultivated by respondents

\begin{tabular}{lllllllll}
\hline & \multicolumn{9}{c}{ Meter squares per year $\left(\mathbf{m}^{\mathbf{2}} / \mathbf{y r}\right)$} & \multicolumn{3}{c}{ Total } \\
\cline { 2 - 8 } & $\mathbf{1 - 2}$ & $\mathbf{2 - 3}$ & $\mathbf{3 - 4}$ & $\mathbf{4 - 5}$ & $\mathbf{5 - 6}$ & $\mathbf{6 - 7}$ & $\mathbf{7 - 8}$ & \\
\hline No. of farmers & 4 & 14 & 17 & 27 & 42 & 75 & 121 & 300 \\
Percentage & 1.3 & 4.7 & 5.7 & 9.0 & 14.0 & 25.0 & 40.3 & $100 \%$ \\
\hline
\end{tabular}

Table 6. Quantities of ginger produced per annum (bags/year) by Farmers

\begin{tabular}{lllllllll}
\hline & \multicolumn{9}{c}{ Bags per year } & \multicolumn{2}{c}{ Total } \\
\cline { 2 - 8 } & $\mathbf{3}$ & $\mathbf{7 . 5}$ & $\mathbf{1 2 . 5}$ & $\mathbf{1 7 . 5}$ & $\mathbf{2 2 . 5}$ & $\mathbf{2 7 . 5}$ & $\mathbf{3 2 . 5}$ & 300 \\
\hline No of farmers & 120 & 75 & 42 & 32 & 15 & 9 & 7 & 100 \\
Percentage & 40.0 & 25.0 & 14.0 & 10.7 & 5.0 & 3.0 & 2.3 & 100 \\
\hline
\end{tabular}

Table 7. Methods of ginger cultivation used by farmers

\begin{tabular}{lllll}
\hline Cultivation method & Flatbed & Mounds & Ridges & Total \\
\hline No. of Farmers & 294 & 0 & 6 & $\mathbf{3 0 0}$ \\
Percentage & 98.0 & 0.0 & 2.0 & $\mathbf{1 0 0}$ \\
\hline
\end{tabular}

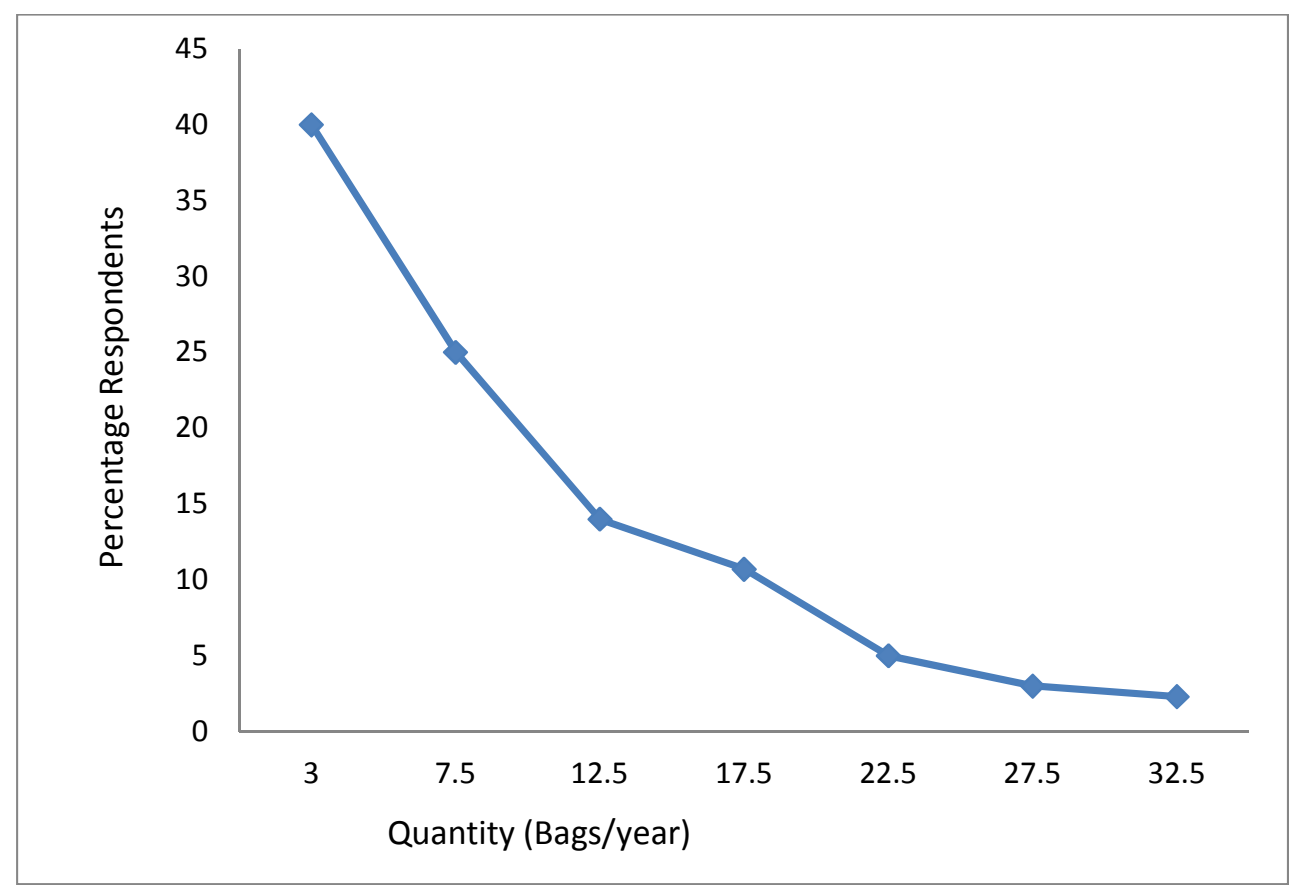

Fig. 2. Annual ginger production levels by individual respondents

\subsection{Data on Ginger Cultivation}

\subsubsection{Inputs used by respondents to boost ginger production}

The respondents in the study area applied one form of input (fertilizer, manure) or the other so as to improve the soil nutrients (Fig. 3). Majority of the respondents used cow manure in place of fertilizers.

\subsubsection{Plant attributes of ginger from experimental farms}

Flatbed treatment recorded the longest leaf (length), the greatest height of plant, wider leaf width, produced more number of leafs and tillers per plant and highest yield; followed by mounds treatment and then ridges (Tables 8 and 9). 


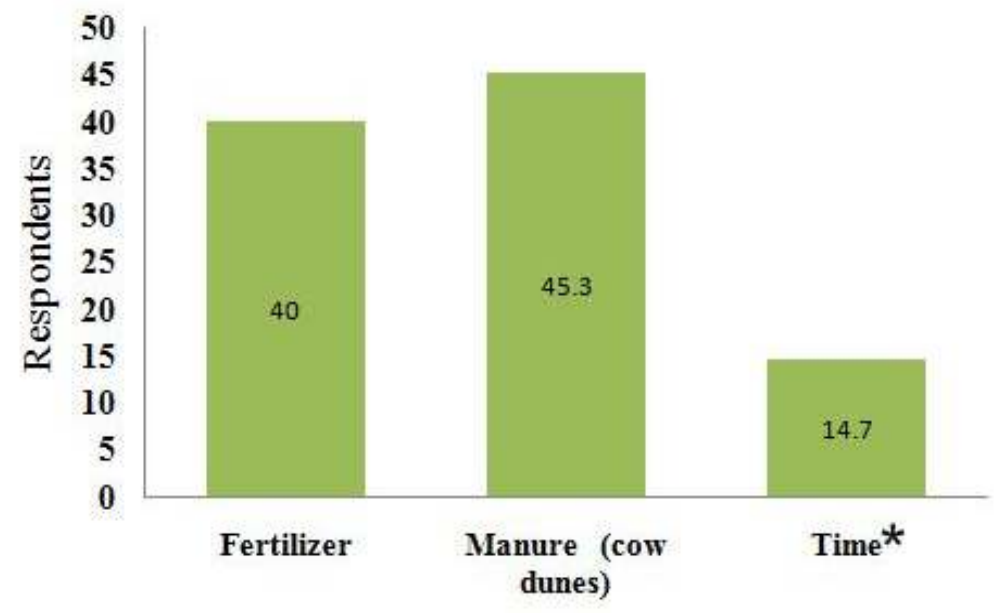

Fig. 3. Farm Inputs Applied to Boost Ginger Yield

Table 8. Plant attributes of ginger crop from the experimental farms

\begin{tabular}{llllllll}
\hline Treatments & \multicolumn{7}{c}{ Plant atributes per sample quadrant $\left(\mathbf{1 . 0 m ^ { 2 } )} \mathbf{( Q )}\right.$} \\
\hline $\begin{array}{l}\text { Tillage } \\
\text { methods }\end{array}$ & Replication & $\begin{array}{l}\text { Number } \\
\text { of } \\
\text { leaves }\end{array}$ & $\begin{array}{l}\text { Heights } \\
\text { of plant } \\
\text { (cm) }\end{array}$ & $\begin{array}{l}\text { Leaf } \\
\text { length } \\
\text { (cm) }\end{array}$ & $\begin{array}{l}\text { Leaf width } \\
\text { of plants } \\
\text { (cm) }\end{array}$ & $\begin{array}{l}\text { No of } \\
\text { tillers }\end{array}$ & $\begin{array}{l}\text { Yield } \\
\text { kg/Qua- } \\
\text { drant }\end{array}$ \\
\hline Flatbeds & $\mathrm{R}_{1}$ & 159 & 26.30 & 21.4 & 2.40 & 3 & 4.50 \\
& $\mathrm{R}_{2}$ & 175 & 29.70 & 21.7 & 2.40 & 2 & 2.20 \\
& $\mathrm{R}_{3}$ & 193 & 33.70 & 21.4 & 2.50 & 3 & 3.40 \\
& $\mathrm{R}_{4}$ & 216 & 36.50 & 22.2 & 2.50 & 3 & 3.50 \\
Mounds & $\mathrm{R}_{5}$ & 233 & 38.30 & 21.5 & 2.30 & 3 & 3.70 \\
& $\mathrm{R}_{1}$ & 151 & 25.70 & 25.7 & 2.30 & 2 & 2.20 \\
& $\mathrm{R}_{2}$ & 161 & 29.80 & 29.8 & 2.10 & 2 & 2.30 \\
& $\mathrm{R}_{3}$ & 174 & 33.60 & 33.6 & 2.20 & 3 & 2.40 \\
& $\mathrm{R}_{4}$ & 189 & 35.60 & 35.6 & 2.10 & 2 & 2.40 \\
& $\mathrm{R}_{5}$ & 204 & 36.50 & 36.5 & 1.90 & 3 & 2.20 \\
Ridges & $\mathrm{R}_{1}$ & 143 & 27.6 & 27.6 & 2.20 & 2 & 2.00 \\
& $\mathrm{R}_{2}$ & 151 & 30.50 & 30.5 & 2.30 & 2 & 2.10 \\
& $\mathrm{R}_{3}$ & 166 & 32.60 & 32.6 & 2.20 & 2 & 1.10 \\
& $\mathrm{R}_{4}$ & 182 & 29.10 & 29.1 & 2.00 & 3 & 2.10 \\
& $\mathrm{R}_{5}$ & 197 & 39.10 & 39.1 & 2.20 & 2 & 0.20 \\
\hline
\end{tabular}

Table 9. Mean attributes of ginger crop from the experimental farms

\begin{tabular}{llllll}
\hline Treatments & \multicolumn{5}{c}{ Mean data per sample quadrant $\left(\mathbf{1 . 0 \mathbf { m } ^ { 2 } )}\right.$} \\
\hline $\begin{array}{l}\text { Tillage } \\
\text { methods }\end{array}$ & $\begin{array}{l}\text { Number } \\
\text { of leaves }\end{array}$ & $\begin{array}{l}\text { Heights } \mathbf{( c m}) \text { of } \\
\text { ginger }\end{array}$ & $\begin{array}{l}\text { Leaf length } \\
(\mathbf{c m})\end{array}$ & $\begin{array}{l}\text { Leaf width }(\mathbf{c m}) \\
\text { of ginger }\end{array}$ & $\begin{array}{l}\text { No. of } \\
\text { tillers }\end{array}$ \\
\hline Flatbed & 195.20 & 32.90 & 21.60 & 2.40 & 2.50 \\
Mounds & 175.80 & 32.20 & 19.50 & 2.20 & 2.20 \\
Ridges & 167.80 & 31.80 & 20.40 & 2.10 & 2.20 \\
\hline
\end{tabular}

\subsubsection{Surface run offs}

The Mounds tillage practice recorded the heaviest mean run-off data followed by ridge tillage while the flatbed recorded the lowest runoff data during the period of study (Table 10).

\subsubsection{Eroded soil data}

Results obtained (Table 11) revealed that eroded soil was highest in the mounds tillage practice, followed by the ridges tillage practice, and the flatbed method recorded the least. 
Table 10. Run off averages $(\mathrm{mm})$ generated from the experimental farms

\begin{tabular}{lllll}
\hline Replications & \multicolumn{3}{c}{ Treatments } & Block \\
\cline { 2 - 5 } & Flatbeds & Mounds & Ridges & Total(yj) \\
\hline $\mathrm{R}_{1}$ & 1715.2 & 2175.1 & 1865.9 & 5756.2 \\
$\mathrm{R}_{2}$ & 1716.7 & 2176.3 & 1867.1 & 5760.2 \\
$\mathrm{R}_{3}$ & 1717.9 & 2177.1 & 1866.9 & 5761.9 \\
Total(yi) & 5148.8 & 6528.5 & 5599.9 & 17278.3 \\
Means(y) & 1716.6 & 2176.2 & 1866.6 & 5759.4 \\
\hline
\end{tabular}

Table 11. Variations in magnitude in soil erosion according to tillage methods

\begin{tabular}{lllll}
\hline \multirow{2}{*}{ Replications } & \multicolumn{3}{c}{ Tillage method and eroded materials $\mathbf{( g / \mathbf { m } ^ { 2 } )}$} & Block \\
\cline { 2 - 5 } & Flatbeds & Mounds & Ridges & Total(yj) \\
\hline $\mathrm{R}_{1}$ & 0.153 & 2.079 & 1.662 & 3.894 \\
$\mathrm{R}_{2}$ & 0.159 & 2.082 & 1.631 & 3.872 \\
$\mathrm{R}_{3}$ & 0.161 & 2.073 & 1.646 & 3.880 \\
Total(yi) & 0.473 & 6.234 & 4.939 & 11.646 \\
Means(y) & 0.158 & 2.078 & 1.646 & 3.882 \\
\hline
\end{tabular}

\section{DISCUSSION}

Of the 300 participants in the study, $61.7 \%$ were not ready to adopt new methods of cultivating ginger crop and this is because most $(90 \%)$ of the Ginger farmers in the study area were found to have formal educational attainment of below tertiary level. In this case, increase in the level of literacy in the study area would increase the farmer's willingness to innovations. This is true and is in line with [7] study, who observed that education is an investment in human capital, which is able to raise the skills and qualities of man, narrows his information gap thereby leading to more productive performance, adoption and diffusion of innovation positively.

The study also revealed that the highest yield of ginger crop was obtained with the Flatbed tillage system. This method of cultivating ginger crop has been the tradition practiced for years in the study area as compared to the other methods (Mounds and Ridges) experimented upon. The reasons for the decline in ginger yield in the study area is linked to the low level of knowledge of the ginger farmers on the use of new methods of farm inputs such as chemical fertilizer application, improved seeds preparations, pesticides application and weeds control. These farm inputs play a major role in determining the yield of ginger crops. This is in agreement with [8] study, in which the evaluated farmers' response to extension service son ginger crop production in Kagarko Local Government Area of Kaduna State. Other factors responsible for the decline in ginger crop production in the study area and southern Kaduna as the major producer of the crop, is attributable to the closure of the ginger processing company located in Kachia (field observation). The company played a major role in encouraging both Ginger farmers and non-ginger farmers, young and old age to embark on large cultivation of the crop, because of its high demand for both local processing and for export. The respondents in the study area applied one form of input (fertilizer, manure) or the other so as to improve the soil nutrients. This finding is similar to [9] work, Integrated Soil Nutrient Management options for Nigerian Agriculture. He recommend the use of such inputs because of the high nutrient contents in either chemical or organic substances, which are capable of improving soil quality and increase yield of cultivated crops.

Plant growth attributes measured during the field work revealed a trend of decrease in all the attributes. The Flatbed treatment recorded the longest leaf length and width, the greatest height of plant, produced more number of leafs and tillers per plant, as well as the highest yield; followed by Mounds and Ridges methods. This may be due to the moisture availability conserved by mulching materials in the flatbeds that enhanced the activities of macro and microorganisms in breaking down food nutrients for the crop's earlier growth, and ability to produce more number of tillers which resulted in the high yield recorded. This result agrees with [10], in their work carried out to determine the effect of tillage and mulch on the growth and yield of ginger in the hilly area of Khamarbari, Dhaka in Bangladesh. The high yield of ginger was recorded where the crop was planted using 
combined tillage practices; tillage with mulching method followed by tillage without mulch practice.

In this study, the Mounds tillage practice was observed to have recorded the heaviest mean run-off data followed by ridge tillage practice while the flatbed recorded the least runoff. The highest value recorded with the mounds practice may be because the mulching materials that were supposed to cover the ground to reduce the velocity of the run-off were a little higher, off the surface of the ground, due to the nature of the tillage formation. In addition to this, the practice also creates a channel which encourages less infiltration rate and more of the rainfall goes into runoff. This is in agreement with $[11,12]$ in their study to find out the effect of mulch cover and trees canopy on soil loss, which recorded the highest amount of run-off under unmulched surfaces with less trees canopy treatment. The lowest run-off values recorded in the flatbed tillage practice may be due to the combined effects of tillage and mulching, as the tillage formed a bed-like structure, hence increasing infiltration and allowing the mulching materials to cover the ground properly as such reducing the amount and the velocity of flow. Hence, the reduction in runoff velocity and high infiltration brought about reduction in transport capacity of the flow. This is consistent with $[13,14]$ findings from his study on soil erosion as a constraint to crop production between the flatbeds and mounds tillage practices in the tropics and where he discovered low impact of rainfall in soil erosion under the flatbed tillage practice.

Results obtained revealed that eroded soil was highest in the mounds tillage practice, followed by the ridges tillage practice, and flatbed tillage practice recoded the least. This may be due to the impact of severe rain drops and a mulching cover a little above the ground to reduce the kinetic energy of the rain drops in the mounds system. The practice also creates more channels which encourage the easy flow of run-off. As such, the quantities of eroded soil particles were more when compared to ridges. In the flatbed tillage method, the impact of rain drops on the soil particles was not much. This is because the mulching materials used were directly on top of the soil and the systems do not create channels to allow the flow of run-off as well as transportation of soil particles. Instead there was high infiltration thereby reducing detachability of soil particles thus making the erosion to be very low.

\section{CONCLUSION}

The study revealed significant increase in the rhizome yield of ginger crop and the highest amount of soil eroded particles on flatbed tillage system as compared to mounds and ridges. Therefore it is recommended that Ginger farmers in the study area should continue with the flatbed method of cultivating ginger, but suggest them to increase their knowledge on soil erosion management and the use of other farming inputs and technologies.

\section{COMPETING INTERESTS}

Authors have declared that no competing interests exist.

\section{REFERENCES}

1. Agbede TM. Nutrient availability and cocoyam yield under different tillage practices. Soil Tillage Res. 2008;99(1):4957.

2. Ojeniyi SO. Comparison of row tillage and no tillage and manual methods. Effect on soil properties and cowpea. In proceedings of the $12^{\text {th }}$ Conference of International Soil Tillage Research Organization. 1991;141145.

3. Kaduna State Agricultural Development Project - KADP. Production of ginger. An extension guide. Kaduna State, Agricultural Development Project, Kaduna; 2000.

4. Arshad MA, Lowery B, Grossman B. Physical tests for monitoring soil quality. Methods for assessing soil quality. (methodsforasses). 1996:123-41.

5. Jakes S, Susan J. Beverage of champions. Times on-line. Archived from the original on; 2007.

6. Iguisi EO. Variation of soil loss in River Kubani sub-Basin Phd Thesis, Ahmadu Bello University Zaria Nigeria; 1996.

7. Orebiyi JS. Economic appraisal of group farming activities in Oyi LGA, Kwara StateNigeria. Unpublished B.Sc. Project, Department of Agricultural Economics, University of Ibadan, Nigeria; 1991.

8. Adegboye MA. Evaluation of farmers response to extension services on ginger production in Kagarko local government area of Kaduna State. Sci. Res. \& Essays; $2011 ; 6(6): 1166-71$.

9. Adetunji MT. Integrated soil nutrient management options for Nigerian agriculture. In managing soil resources for 
food security and sustainable environment. $20^{\text {th }}$ Annual Conference of the Soil Science Society of Nigeria, Abuja, Nigeria. 2004; 189-195.

10. Zaman MM, Masum ASMH, Ahmed NU, Salam MA, Rahman MH. Effect of tillage and mulch on the growth and yield of ginger in the hilly area. OnLine $\mathrm{J}$ Biol Sci (Pakistan); 2002.

11. Khan MJ, Monke EJ, Foster GR. Mulch cover and canopy effect on soil loss. Transactions of the ASAE. 1988; 31(3):706-0711.
12. Smets $\mathrm{T}$, Poesen J, Bochet E. Impact of plot length on the effectiveness of different soil-surface covers in reducing runoff and soil loss by water. Progress Phys Geog. 2008;32(6):654-77.

13. Lal R. Tillage effects on soil degradation, soil resilience, soil quality, and sustainability. Soil and Tillage Res. 1993; 27(1):1-8.

14. Khurshid KA, lqbal MU, Arif MS, Nawaz AL. Effect of tillage and mulch on soil physical properties and growth of maize. Int J Agric Biol. 2006;8(5):593-6. 


\section{APPENDIX I}

Test for mean difference of ginger yield produced among the types of tillage treatments

\begin{tabular}{|c|c|c|c|c|c|c|}
\hline \multirow[t]{2}{*}{ Quadrants } & \multicolumn{6}{|c|}{ Treatments yield Kg/Quadrant } \\
\hline & $x_{1}$ & $x_{1}^{2}$ & $x_{2}$ & $x_{2}^{2}$ & $x_{3}$ & $x_{3}^{2}$ \\
\hline 1 & 4.50 & 2.25 & 2.20 & 4.84 & 2.00 & 4.00 \\
\hline 2 & 2.20 & 4.84 & 2.30 & 5.29 & 2.10 & 4.41 \\
\hline 3 & 3.40 & 11.25 & 2.40 & 5.76 & 1.10 & 1.21 \\
\hline 4 & 3.50 & 12.25 & 2.40 & 5.76 & 2.10 & 4.41 \\
\hline 5 & 3.70 & 13.69 & 2.20 & 4.84 & 0.20 & 0.04 \\
\hline Total & 17.30 & 63.59 & 11.50 & 26.49 & 7.5 & 14.07 \\
\hline
\end{tabular}

\section{Calculation Procedures}

Step 1:- $\mathrm{H}_{0}$ : The means of the three treatments are equal

$$
\left(\mu x_{1}=\mu x_{2}=\mu x_{3}\right)
$$

$\mathbf{H}_{\mathrm{i}}$ At least two treatments mean differ

Step 2:- Select the appropriate test statistic.

The test statistic is the F statistic for Analysis of variance (ANOVA)

$$
\begin{aligned}
& \mathrm{F}=\frac{\text { Between }- \text { group Variability }}{\text { Within-group Variability }}=\frac{M S T}{M S E} \\
& \text { But } M S T=\frac{\sum_{i=1}^{n_{i}}\left(\overline{x_{i}} x\right)^{2}}{K-1}=\frac{S S T}{K-1}
\end{aligned}
$$

Where:

$\overline{x_{i}}=$ sample mean in $i^{\text {th }}$ group

$n_{\underline{i}}=$ the number of observations in the $i^{\text {th }}$ group

$\bar{x}=$ overall mean of the data

$k=$ number of treatment $=3$

$\mathrm{MST}=$ mean squares for treatments

$\mathrm{SST}=$ sum squares for treatments

While $M S E=\frac{\sum_{i j}\left(x_{i j}-\overline{x_{i}}\right)^{2}}{n-k}=\frac{S S E}{n-k}$

Where: $x_{i j}=j^{\text {th }}$ observation in the $i$ out of $K$ groups

$n=$ overall saple size

MSE = mean squares for error

$\mathrm{SSE}=$ sum squares for error

Step 3:- Computing the test statistic.

Step 4:- Set up decision rule.

The appropriate critical value can be found in a table of probabilities for the $\mathrm{F}$ distribution. In order to determine the critical value of $F$ we need degrees of freedom, $d f_{1}=\mathrm{k}-1$ and $d f_{2}=\mathrm{n}-\mathrm{k}$. In this example, $d f_{1}=3-1=2$ and $d f_{2}=15-3=12$ at $\propto=0.05$. The critical value $F_{t}$ is 3.89 and the decision rule is as follows: Reject $\mathrm{H}_{0}$ if $F_{c}>3.89$. 
Calculate the Correction for the Mean (CM)

$$
\begin{aligned}
& =\frac{\left(\sum_{i=1}^{n} x_{i}\right)^{2}}{n}=\frac{\left(x_{1}+x_{2}+x_{3}\right)^{2}}{n}=\frac{(17.30+11.50+7.50)^{2}}{15}=\frac{(36.3)^{2}}{15}=\frac{1317.69}{15}=87.85 \\
& \mathrm{SST}=\frac{\left(\sum x_{1}\right)^{2}}{n_{1}}+\frac{\left(\sum x_{2}\right)^{2}}{n_{2}}+\frac{\left(\sum x_{3}\right)^{2}}{n_{3}}-\mathrm{CM} \\
& =\frac{(17.30)^{2}}{5}+\frac{(11.50)^{2}}{5}+\frac{(7.50)^{2}}{5}-87.85 \\
& =\frac{299.29}{5}+\frac{132.25}{5}+\frac{56.25}{5}-87.85 \\
& =59.86+26.45+11.25-87.85 \\
& =97.56-87.85 \\
& =9.71 \\
& \mathrm{MSE}=\frac{S S E}{n-k}
\end{aligned}
$$

Where SSTot $=$ sum squares for total

$$
\begin{aligned}
\text { SSTot } & =\sum_{i=1}^{n} x_{i}^{2}-\mathrm{CM} \\
& =63.59+26.49+14.07-87.85 \\
& =104.15-87.85 \\
& =16.30 \\
\text { SSE } & =\text { SSTot- SST } \\
& =16.30-9.71 \\
& =6.59 \\
\text { MST } & =\frac{S S T}{K-1}=\frac{9.71}{3-1}=\frac{9.71}{2}=4.86 \\
\text { MSE } & =\frac{S S E}{n-K}=\frac{6.59}{15-3}=\frac{6.59}{12}=0.55 \\
\text { Therefore } \mathrm{F}_{\mathrm{t}} & =\frac{M S T}{M S E}=\frac{4.86}{0.55}=8.84 \text { (calculated value) }
\end{aligned}
$$

(ANOVA) between Tillage Methods and Yield

\begin{tabular}{lllll}
\hline Sources & Df & SS & MS & F \\
\hline Treatments & 2 & 9.71 & 4.86 & 8.84 \\
Error & 12 & 6.59 & 0.55 & \\
Total & 14 & 16.30 & & \\
\hline \multicolumn{5}{c}{ Significant difference at 0.05 levels of probability }
\end{tabular}


The test result shows that method of tillage has significant effect on the production of ginger crop. Since the calculated F- value 8.84 is greater than the critical value 3.98 at 0.05 probability level. Therefore the null hypothesis $\left(\mathrm{H}_{0}\right)$ is rejected because the data provide sufficient evidence to conclude that at least two treatments means differ in yield produced per kilogram per quadrant.

\section{APPENDIX II}

Test for the mean differences of eroded soils obtained among types of tillage system practiced

\begin{tabular}{lllllll}
\hline Rainfall $(\mathbf{m m})$ & \multicolumn{6}{c}{ Eroded soils obtained $\mathbf{m m}$ /rainfall/Treatment } \\
\cline { 2 - 7 } & $\boldsymbol{y}_{\mathbf{1}}$ & $\boldsymbol{y}_{\mathbf{1}}^{\mathbf{2}}$ & $\boldsymbol{y}_{\mathbf{2}}$ & $\boldsymbol{y}_{\mathbf{2}}^{\mathbf{2}}$ & $\boldsymbol{y}_{\mathbf{3}}$ & $\boldsymbol{y}_{\mathbf{3}}^{\mathbf{2}}$ \\
\hline 20.0 & 0.220 & 0.050 & 0.337 & 0.114 & 0.313 & 0.098 \\
30.0 & 0.313 & 0.098 & 1.925 & 3.706 & 1.901 & 3.614 \\
12.0 & 0.037 & 0.001 & 0.419 & 0.176 & 0.512 & 0.262 \\
35.0 & 0.329 & 0.108 & 1.687 & 2.846 & 1.785 & 3.186 \\
17.0 & 0.094 & 0.009 & 0.571 & 0.326 & 0.503 & 0.253 \\
19.0 & 0.068 & 0.005 & 0.600 & 0.360 & 0.360 & 0.130 \\
40.0 & 0.978 & 0.956 & 1.770 & 3.133 & 1.820 & 3.312 \\
45.0 & 1.905 & 3.629 & 2.006 & 4.024 & 1.900 & 3.610 \\
15.0 & 0.075 & 0.006 & 1.740 & 3.028 & 0.283 & 0.080 \\
17.0 & 0.051 & 0.003 & 0.515 & 0.265 & 0.109 & 0.012 \\
Total & 4.070 & 4.820 & 10.570 & 17.660 & 9.484 & 14.557 \\
\hline
\end{tabular}

Where,$y_{1}=$ Flatbed Tillage,$\quad y_{2}=$ Mound Tillage $\quad y_{3}=$ Ridges Tillage

$\mathbf{H}_{0}$ : The means of the three treatments are equal

$$
\left(\mu y_{1}=\mu y_{2}=\mu y_{3}\right)
$$

$\mathbf{H}_{\mathrm{i}:}$ At least two treatments mean differ

The test statistic is the $\mathrm{F}$ statistic for Analysis of variance (ANOVA) $\quad \mathrm{F}_{\mathrm{t}}=\frac{M S T}{M S E}$

Decision rule; In this example, $d f_{1}=k-1=3-1=2$ and $d f_{2}=n-b-k+1=30-10-3+1=18$, at, $\propto=0.05$ The critical value $F_{t}$ is 3.55 and the decision rule is as follows: Reject $\mathrm{H}_{0}$ if $F_{c}>3.55$

Computing the test statistics.

$\sum_{i=1}^{n} y_{i}^{2}=4.823+17.819+14.557=37.199$

Correction for the means $(\mathrm{CM})=\frac{\left(\sum_{i=1}^{n} y_{i}\right)^{2}}{n}=\frac{24.124^{2}}{30}=\frac{581.197}{30}=19.399$

$$
\begin{aligned}
& \begin{aligned}
\text { SSTot }=\sum_{\mathrm{i}=1}^{\mathrm{n}} \mathrm{y}_{\mathrm{i}}^{2} & =\mathrm{CM} \\
& =37.037-19.399 \\
& =17.638
\end{aligned} \\
& \begin{aligned}
\mathrm{SST} & =\frac{\left(\sum y_{1}\right)^{2}}{b_{1}}+\frac{\left(\sum y_{2}\right)^{2}}{b_{2}}+\frac{\left(\sum y_{3}\right)^{2}}{b_{3}} \text { Where } \mathrm{b}=\text { number of blocks (number of rainfall collected) } \\
= & \frac{4.070^{2}}{10}+\frac{10.570^{2}}{10}+\frac{9.484^{2}}{10}-19.399 \\
= & 21.825-19.399 \\
= & 2.426
\end{aligned}
\end{aligned}
$$




$$
\begin{aligned}
\text { SSB } & =\text { Sum Squares for blocks } \\
& =\frac{b_{i}^{2}}{k}+\frac{b_{2}^{2}}{k}+\cdots+\frac{b_{10}^{2}}{k} \\
& =\frac{0.870^{2}}{3}+\frac{4.139^{2}}{3}+\cdots+\frac{0.675^{2}}{3}-19.399 \\
& =31.74-19.399 \\
& =12.34
\end{aligned}
$$

SSE $=$ SSTot- SST- SSB

$=17.638-2.426-12.34$

$=2.872$

MST=Mean Square for treatments $=\frac{S S T}{k-1}=\frac{2.426}{3-1}=1.213$

MSE $=$ Mean Square for error $=\frac{S S E}{n-B-k+1}=\frac{2.872}{30-10-3+1}=\frac{2.872}{18}=0.160$

Thus: $\mathrm{F}_{\mathrm{t}}=\frac{M S T}{M S E}=\frac{1.213}{0.160}=7.58$

ANOVA Summary Table

\begin{tabular}{lllll}
\hline Sources & Df & SS & MS & F \\
\hline Treatments & 3 & 2.426 & 1.213 & 7.58 \\
Error & $\mathrm{n}-\mathrm{k}$ & 2.872 & 0.160 & \\
Total & $\mathrm{n}-1$ & 17.638 & & \\
\hline \multicolumn{5}{c}{ Significant difference at 0.05 levels of probability }
\end{tabular}

The ANOVA calculated for the soil particle data obtained. The hypothesis test revealed that, calculated value of $\left(F_{c}\right)=7.58$ is greater than the critical value $\left(F_{t}\right)=3.55$ at 0.05 probability level. Therefore the null hypothesis is rejected $\left(\mathrm{H}_{0}\right)$ and the alternative hypothesis is hereby accepted. And hence we conclude that the tillage method practiced in ginger production has a significant effect on the quantity of soil particle removed per gram, because the data provide sufficient evidence to conclude at least two treatments mean differ. The experiment was considered reliable, vegetated water ways and mode of tillage practiced on the farm checks (velocity breaks) are good management practices to check erosion. 


\section{APPENDIX III}

Test for the Relationship between Educational Attainment and Readiness To Adopt New Methods of Farming Ginger

\begin{tabular}{|c|c|c|c|c|c|}
\hline & $x$ & $y$ & $x^{2}$ & $y^{2}$ & $x y$ \\
\hline Never been to school & 7 & 0 & 0 & 49 & 0 \\
\hline Adult Education & 10 & 4 & 16 & 100 & 40 \\
\hline Primary school & 125 & 35 & 1225 & 15625 & 4375 \\
\hline Secondary School & 43 & 47 & 2209 & 1849 & 2021 \\
\hline Tertiary Education & 0 & 29 & 841 & 0 & 0 \\
\hline Total & 185 & 115 & 4291 & 17623 & 6436 \\
\hline
\end{tabular}

Hypothesis:

$\mathbf{H}_{0}=$ The coefficient for the correlation is zero $(\rho=0)$

$\mathbf{H}_{\mathbf{i}}=$ The coefficient for the correlation is not zero $(\rho \neq 0)$

Pearson's correlation coefficient hypothesis test

$\mathrm{t}_{\mathrm{c}}=\frac{r}{\sqrt{\frac{1-r^{2}}{n-2}}}$ but first Correlation Coefficient $(r)$ is calculated:

$$
\begin{aligned}
r= & \frac{s s_{x y}}{\sqrt{s s_{x x} * S s_{y y}}} \\
S s_{x y} & =\sum x y-\frac{\sum x \sum y}{n}=6436-\frac{115 * 185}{5} \\
& =6436-\frac{21275}{5} \\
& =6436-4255 \\
& =2181 \\
s s_{x x}= & \sum x^{2}-\frac{\left(\sum x\right)^{2}}{n}=4291^{2}-\frac{(115)^{2}}{5} \\
= & 18412681-\frac{13225}{5} \\
= & 18412681-2645 \\
= & 18410036 \\
s s_{y y}= & \sum x^{2}-\frac{\sum y^{2}}{n}=17623^{2}-\frac{(185)^{2}}{5}=310563284 \\
= & 310570129-\frac{34225}{5} \\
= & 310570129-6845 \\
= & 310563284
\end{aligned}
$$




$$
r=\frac{s s_{x y}}{\sqrt{s s_{x x}} * s s_{y y}}=\frac{2181}{\sqrt{18410036} * 310563284}=0.00003
$$

The Pearson's correlation coefficient hypothesis test:

$$
t_{c}=\frac{r}{\sqrt{ } \frac{1-r^{2}}{n-2}}=\frac{0.0003}{\sqrt{\frac{1-0.0003^{2}}{5-2}}}=9.09
$$

Rejection region at $\alpha=0.025$ (two tail)

$$
\mathrm{df}=\mathrm{n}-2=5-2=3
$$

The critical value $t_{t}$ is 3.18 and the decision rule is as follows:

Reject $\mathrm{H}_{0}$ if $t_{c}>3.18$ or $<-3.18$, therefore, our data provided sufficient evidence, at $\alpha=0.025$ to conclude that the Pearson's coefficient of relation for the respondents is different than zero

\section{APPENDIX IV}

Dear sir/Madam

I am a student of Nigerian Defense Academy Post Graduate School Kaduna, undertaking a research work on a topic Comparative Analysis of Ginger Cultivation Methods in Kurmin-Jatau District of Jaba Local Government Area, Kaduna State, as part of my Master Degree program. The purpose of this questionnaire is to gather relevant information for the research work. I therefore solicit your cooperation in providing correct answers to the questions provided below. All information provided shall be used for academic purposes and kept confidential.

Instructions: Answer each question by ticking the box provided.

\section{Personal Data}

1 Sex: Male

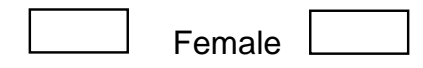

2 Age: $25-30$
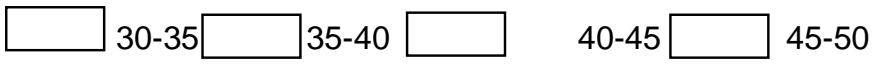

\section{Data on Method of Ginger Cultivation}

1. How long have you been a Ginger Farmer?

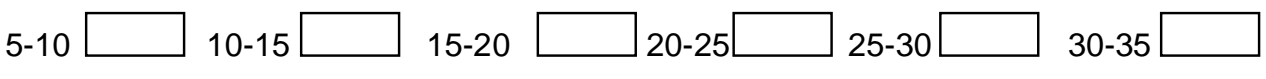

$35-40$

2. Size of Ginger farm normally cultivated in Hectares?

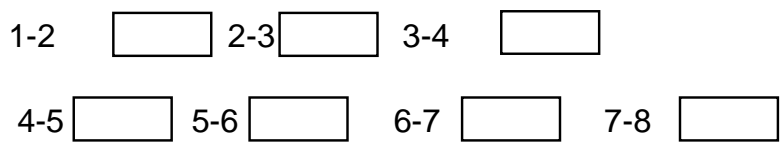

3. Methods of ginger cultivation practiced 
4. Do you know other methods of Ginger cultivation?

Yes $\square$ No $\square$

5. Which among these methods do you know Flatbed $\square$ Mounds $\square$ Ridges $\square$

6. Which method have you ever practiced apart from the one normally practiced?

Flatbed $\square$ Mounds $\square$ Ridges $\square$

7. Are you currently practicing the method selected in 4 above?

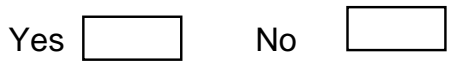

8. How many bags of Ginger do you produce per year?

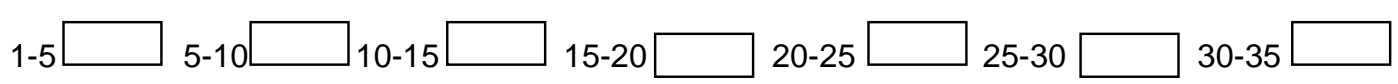

9. Do you still cultivate Ginger now?

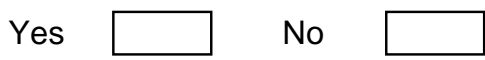

10. What is the level of production now (in bags)?

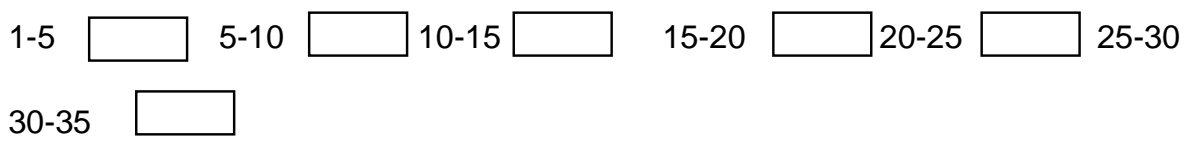

11. Do you employ any additional labor?

Yes No

12. If yes, what type?

Cow dung $\square$ Chemical Fertilizer $\square$ Spend more time than before $\square$

13. Are you ready to accept and adopt an alternative method of cultivation if it will give a better yield?

Yes $\square$ No $\square$

\section{Data on Knowledge of Erosion}

14 Have you ever heard of the word erosion?

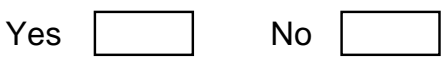

15 Do you experience erosion on your ginger farm?

Yes

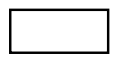

No 
16 To what extent do you experience erosion?

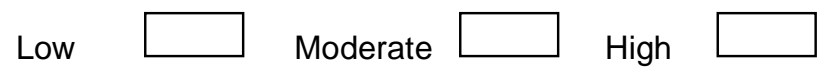

17 Do you know that erosion can contribute to decrease in ginger yield productivity?

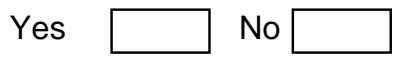

18 Do you think the decrease in your ginger yield productivity is due to erosion?

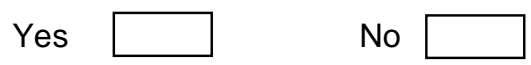

19 What measures have you taken to check out erosion?

Mulching $\square$ Change in mode of Tillage $\square$ Fertilizer application $\square$

(C) 2017 Sati and Bala; This is an Open Access article distributed under the terms of the Creative Commons Attribution License (http://creativecommons.org/licenses/by/4.0), which permits unrestricted use, distribution, and reproduction in any medium, provided the original work is properly cited.

Peer-review history:

The peer review history for this paper can be accessed here:

http://sciencedomain.org/review-history/19713 